\title{
Çağrı Merkezi Çalışanlarında İş-Aile Çatışması Algısı Üzerine Ampirik Bir İnceleme
}

\author{
Fatma YILMAZ*
}

Öz

Günümüz ekonomisinde birçok çalışan iş-aile çatışmasıyla ilgili sıkıntı yaşamaktadır. İş-aile çatışması meselesi, işgücündeki büyük demografik değişiklikler ve birçok organizasyonun son yıllarda karşılaştığı rekabetçi çalışma ortamları nedeniyle artan bir ilgi görmektedir. İş hayatını ve aile hayatını dengelemek, sadece birey için değil organizasyon için de giderek kritik bir konu haline gelmektedir. Özellikle çağrı merkezlerinde yoğun çalışma koşulları nedeniyle iş-aile çatışması surumu ortaya çıkabilmektedir. Bu çalışmanın amacı çağrı merkezi çalışanlarında iş-aile çatışmasının belirlenmesidir. Bu doğrultuda çalışmanın örneklemini Erzincan ilinde bulunan bir çağrı merkezinde çalışan 287 katılımcı oluşturmaktadır. İş-aile çatışması ve aile-iş çatışması şeklinde iki boyut katılımcıların demografik değisşkenleri ile ilişkilendirilmiştir. Çalışmada SPSS paket programı kullanılarak t-testi ve Anova testi gerçekleştirilmiş olup çeşitli sonuçlar elde edilmiştir. Bu sonuçlardan bazıları şu şekildedir; kadın çalışanların erkek çalışanlara göre ve evli çalışanların bekâr çalışanlara göre daha fazla çatışma yaşadıkları ortaya çıkmıştır.

Anahtar Kelimeler: Çatışma, İş-Aile Çatışması, Aile-İş̧ Çatışması, Davranış, Çağrı Merkezi

Jel kodları: M10, M12

\section{An Empirical Study on Work-Family Conflict in Call Center Workers}

\section{Abstract}

In today's economy, many employees experience difficulties with work-family conflict. The issue of work-family conflict is gaining increasing attention due to the large demographic changes in the workforce and the competitive working environments that many organizations have encountered in recent years. Balancing business and family life is becoming an increasingly critical issue not only for the individual but also for the organization. Especially in call centers, work-family conflict situation may arise due to intense working conditions. The aim of this study is to determine work-family conflict in call center employees. Accordingly, the sample of the study consists of 287 participants working in a call center in Erzincan. Two dimensions, namely work-family conflict and family-work conflict, are associated with the demographic variables of the participants.

\section{Özgün Araştırma Makalesi (Original Research Article) \\ Geliş/Received: 23.03.2019 \\ Kabul/Accepted: 17.03 .2020 \\ DOI: https://dx.doi.org/10.17336/igusbd.542494}

* Dr. Öğr. Üyesi, Erzincan Binali Yıldırım Üniversitesi, Üzümlü Meslek Yüksekokulu, Erzincan,

Türkiye, E-posta: ffatmaayilmaz@gmail.com ORCID https://orcid.org/0000-0001-8065-7245 
In the study, t-test and Anova test were performed using SPSS package program and various results were obtained. Some of these results are as follows; It has been revealed that female employees experience more conflict than male employees and married employees have more conflict than single employees.

Center

Keywords: Conflict, Work-Family Conflict, Family-Work Conflict, Behavior, Call

JEL CODES: M10, M12

\section{Giriș}

Hizmet sektöründeki değişikliklerin bir sonucu olarak, çağrı merkezleri hızla büyümeye başlamıștır. 20. yüzyılın başlarında faaliyete geçen çağrı merkezleri, modern kurumsal dünyada merkezi bir yere sahiptir. Çağrı merkezleri günümüzde büyük önem kazanmıştır, çünkü müşteri ilişkileri yönetimi gibi müşteri odaklı bir yaklaşım, özellikle son on yılda modern hizmet anlayışına genel kabul görmüş bir yaklaşımdır.

Küreselleşmeyle birlikte teknoloji ve inovasyondaki ilerlemeler dünya pazarlarında yeni hizmet, ürün ve iletişim türlerinin ortaya çlkmasına neden olmuştur. Tüm bu değişiklikler arasında, gelişmiş ve gelişmekte olan ülkelerde hizmet sektörünün büyüme hızının önemli olduğu ve bu değişikliklere göre hizmetler sektörünün artık imalat sektörünü destekleyen bir çevresel faaliyet olarak görülmediği belirtilmektedir (Wirtz, 2000: 37). Özellikle çağrı merkezlerinde çalışma ve örgütsel / örgütsel psikoloji ile ilgili olarak son yıllarda oldukça gündemde olan çağrı merkezleri, temel olarak işletmelerin müşterilere kolayca ulaşma, onların sorun ve problemlerini çözebilme ya da müşterilere yönelik faaliyetlerde daha etkili olabilme gayesine dayanmaktadır. Çağrı merkezi çalışmalarının yazında sıklıkla yer alıyor olmasının ana sebebi, çağrı merkezlerinin çalışma tarzları ve yapılarından ileri gelmektedir. Taylorizmin tekrar doğuşu şeklinde de ifade edilen bu çalışma şekli bireylerin rutin bir çalışma durumuna hapsolmuş oldukları ve yoğun iş yükü altında kaldıklarını işaret etmektedir (Keser, 2006: 100-101). Teknolojinin gelişmesi, yüksek nitelikli çalışanların artan kullanımı ve artan ihtiyacı ile çağrı merkezleri, müşteri desteği kavramının gelişmesine yol açmış, sadece telefon görüşmeleri yaparak basit işler bırakılmıştır. Bir müşteri temsilcisinin kaliteli hizmet verebilmesi için sektörün içeriği hakkında bilgiye ihtiyacı vardır. Böylece, hızla büyüyen telekomünikasyon ve finans sektörlerinde müșteri destek merkezleri hızla gelişmektedir (Batt \& Moynihan 2002: 15). Günümüzün teknolojik gelişmeleri sayesinde, iletişimde şeffaflık, kuruluşların her türlü eylemini daha görünür hale getirmektedir (Ay ve Kumkale, 2020: 2). Müșteriler tarafından bildirilen sorunları çözmek, şikâyetlere hızlı bir şekilde yanıt vermek, müşterilerle gerekli bilgileri paylaşmak için 7 gün, 24 saat ve yılın her günü kullanılabilen bir sisteme "çağrı merkezi" denmektedir (Prahabkar, MJ \& Coppett, 1997: 223).

Çağrı merkezleri araştırmacılar tarafından hem endüstriyel ilişkilerdeki yeri hem de çalışanlarının ekonomik, sosyal ve psikolojik koşulları açısından araştırılmıştır ve çağrı merkezlerinin çalışanlar açısından bir takım olumsuz sonuçlar doğurduğu ileri sürülmüştür. Bu olumsuz sonuçların temel nedenleri arasında, yüksek iş yükü ve yöneticiler tarafından sürekli kontrol gelmektedir (Başbuğ, Ballı \& Oktuğ, 2010: 260). Çağrı merkezi çalışanlarının müşterileri ile olan görüşmeleri sürekli olarak izlenmekte ve çalışanların performansı, verilen hizmetlerle ilgili bir hareket-zaman etüdüyle değerlendirilmektedir. Çalıșanın günlük olarak görüştüğü müşteri sayısı, müşterilere yönelik üslubu, çözüme ait yaklaşımı ve sunmuş olduğu çözümlerin soruna temas etme düzeyi sürekli izlenerek değerlendirmeye tabi tutulmaktadır. Yapılan araştırmalar neticesinde, çağrı merkezinde çalışmanın çalışanlar için yüksek stres getirisi olduğu 
ortaya konmuştur (Taylor \& Bain, 1999: 102). Çağrı merkezlerinde işe ilişkin bölünmelerin fazlalığı, tekdüze çalışma, çalışanın görüşlerini ifade etme esnekliğinin olmaması ve sonuçta kişisel becerilerin sınırlı kullanımı ve iş üzerinde minimum kontrol gibi birçok olumsuz durum vardır (Lewig \& Dollard, 2003: 368). 1999 yılında Isı, Dormen ve Zapf tarafından 250 ofis ve çağrı merkezinde çalışanlarla yapılan bir çalışmada; çağrı merkezi çalışanlarının ofis çalıșanlarından daha yoğun psikosomatik şikâyetler gösterdiği ortaya çıkmıştır. Çalışanlar, müşterileri çağrı merkezinde karşılaştıkları sorunlar hakkında bilgilendirmenin yanı sıra, kendilerine ve iş dünyasına yönelik olumsuz tutumlarında gösterdikleri kaba, aşağılayıcı ve hakaret edici konuşmaları sakin bir şekilde dinlemek için yoğun duygusal çabalar gösterirler. Bu bağlamda, bir çağrı merkezinde çalışmanın çalışanlar üzerinde son derece olumsuz bir etkisi olabilmektedir (Zapf, Isic, Bechtoldt \& Blau, 2003: 332).

Ülkemizde çağrı merkezi çalışanları çeşitli çalışmalarda araştırma konusu olmuştur. Parlak ve Çetin (2007) tarafından yapılan bir araştırmada; özel bankaların çağrı merkezlerinde iş süreci, iş ve istihdam konuları incelemiş ve buralarda yapılan çalışmanın monoton, rutin, bıktırıcı ve sıkıcı olduğu sonucuna varılmıştır. Buna ek olarak, bu çalışma çağrı merkezi çalışanlarının çalışmalarından stresli ve memnun olmadıklarını, çünkü inisiyatif kullanamayacaklarını ve işlerini yaparken kendilerini geliştiremeyeceklerini ve sürekli gözetim ve değerlendirmeye tabi olduklarını belirtmiștir. Keser (2006)'de benzer bir çalışma ile bankalardaki çağrı merkezlerinde çalışanların iş tatmini ve iş yükü ilişkisini araștırmıştır. Sonuç olarak iş yükünün yüksek ve iş tatmininin düşük oluğu ileri sürülmüştür. Selek ve Man (2007) tarafından yapılan çalıșma ise yerel ve yabancı sermayeli iki bankanın çağrı merkezlerinde gerçekleștirmiş olup çalışma sonucunda, çağrı merkezlerinde görev yapmanın çalışanları psikolojik anlamda tükettiğini, çalışanların hakları olan ücretleri alamadıkları ve çalışanların iş başında her zaman kontrol edildiği yönünde bulgulara ulaşmışlardır. Öz (2007)'ün çalışmasında ise duygusal emeğin işe bağlılık ve işten ayrılma niyeti gibi örgütsel sonuçlar arasındaki ilişkiye aracılık ettiğini belirlemiştir.

Çağrı merkezlerinde iş-aile çatışması konusunu incelemek için ülkemizde yapılan sınırlı sayıda çalışma, bu konuda yeni araştırmalara ihtiyaç olduğunu göstermektedir. Bu çalışmanın amacı çağrı merkezi çalışanlarının iş-aile çatışması ve aile-iş çatışmasının incelemektir.

Çatışma, iki veya daha fazla bireyin hedeflerinin, isteklerinin ve amaçlarının birbiri ile uyum içerisinde olmaması durumudur. Başka bir tanıma göre çatışma, bireyler ve gruplar arasındaki sürtüşmeler ve anlaşmazlıklar neticesinde meydana gelen duygusal ortamlardır (Çarıkçı \& Çelikkol, 2009: 154). İş aile çatışması, işin ve ailenin alanından kaynaklanan durumlarında karşılıklı şekilde uyumsuz roller içerisinde kișilerin yașamıș olduğu çatışma türü biçiminde ifade edilmektedir (Aktaş \& Gürkan, 2015: 140). İş-aile çatışması kişinin kendisi ile işi arasında veya ailesi ile iși arasında oluşan uyumsuzluk olarak tanımlanmaktadır (Efeoğlu \& Özgen, 2007: 238). Literatürde çalışanların işleri ve aileleri için ayırdıkları zaman, çalışanların ruhsal sıkıntıları ve toplum içindeki sosyal ilișkilerine göre farklı türde iş-aile çatışmaları ortaya konulmaktadır. Konuya ilișkin literatür incelendiğinde iş-aile çatışmasının üç çeşidi olduğu görülmektedir. Bunlar (Carlson, 1999: 237):

Zaman esaslı çatışma; zamanın eşit olmayan dağılımından kaynaklanan çatışma türüdür. Bir kişi birden fazla rol oynarsa ve her bir role yeterli zaman atanmazsa, sınırlı bir süre için rol yarışmasına neden olmaktadır (Lu, Cheng \& Huang, 2015, s. 1030)

Gerginlik esaslı çatışma; gerilime dayalı çatışma, bir rolün yarattığı stres ve gerginliği, başka bir rolün yerine getirilmesi taleplerini engellemektedir (Mozafari, Azami, Dehkordi \& Aazami, 2016: 165). Gerilime dayalı çatışma, işyerinde yaşadığı stresin, aile içindeki rollerin taleplerini karşılamasını zorlaştırdığı zaman ortaya çıkmaktadır. 
Örneğin, iş stres kaynaklarının yarattığı olumsuz duygular, aile üyelerine yönelik öfkenin ifadesine yol açabilir veya bunun tersi de yaşanabilmektedir (Kalliath \& Kalliath, 2013, s. 243). İş ve aile rollerinin artan talepleri daha fazla iş-aile çatışmasına neden olmaktadır (Yılmaz, 2019: 143).

Davranış esaslı çatışma; bir roldeki gerekli davranışın uygunsuz, uyumsuz olması ve başka bir alanla etkisiz olması davranış temelli çatışmayı ortaya çıkmaktadır (Mozafari, vd., 2016: 165). Bu tür çatışma, bireylerin aile veya iş hayatında üstlenmiş olduğu rollere (iş hayatında başarılı ve girișken olan bireylerin, aile yaşamı içerisinde de sıcak ve hoşgörülü davranmasının beklenmesi gibi) uygun biçimde gerçekleştirdiği davranışların bireylerin diğer yaşam alanlarında da sergilemiş olduğu davranışlar ile uyum göstermeyebilmesi ve bunun da çatışmaya neden olabilmesidir (Sunal, Ok \& Keskin, 2016: 145).

İş-aile çatışması olarak tek taraflı olmayıp iş ve aile alanları arasında karşılıklı gerçekleşmektedir (Wayne, Musisca \& Fleeson, 2004: 108). Buna göre iş-aile çatışmasının yönleri şunlardır (Greenhaus \& Beutell, 1985): İş-aile çatışması ve aile-iş çatışması. İșailesi çatışması çift yönlüdür, bu durum da iş konularının evde çatışmalara neden olabileceği veya evdeki sorunların işyerinde çatışmaya neden olabileceği anlamına gelmektedir (Lambert, Qureshi, Frank, Keena \& Hogan, 2016: 38). İş-aile çatışması araştırmalarda, işle ilgili taleplerin aile sorumluluklarını yerine getirmeyi zorlaștıran işten aileye çatışma ile aile ile ilgili taleplerin iş sorumluluklarını yerine getirmeyi zorlaştıran aileden işe çatışma șeklinde ele alınmıștır (Dixon \& Bruening, 2005: 228).

İş-Aile Çatışması: Bireylerin işiyle ilgili almış olduğu sorumlulukların ailesiyle ilgili sorumluluklarını yerine getirmesini engellediği zaman oluşan çatışma türü iş-aile çatışması olarak adlandırılmaktadır. Bu durum kişinin ailesi ile ilgili sorumluluk alanında, kişinin sorumluluğunu yerine getirememesine, dolayısıyla kişinin mutsuz olmasına, hayat kalitesinin düşmesine neden olmaktadır (Giray \& Ergin, 2006: 84). İş ve yaşam alanları birbirinden bağımsız olmamakla birlikte kişi rollerinin gerçekleştirildiği alanların kesiștiği noktalar da bulunmaktadır. Bireylerin işleri gereği yaptıklarının aileye ait sorumluluklarının yerine getirilmesini engellediği için meydana gelen çatışma ya da işinden ailesine yönelik yaşadığı çatışma türü iş-aile çatışmasıdır (Özdevecioğlu \& Aktaş, 2007: 7). İş-ailesi çatışması, "genel taleplerin, ayrılan zamanın ve iş tarafından yaratılan gerginliğin aile ile ilgili sorumlulukların yerine getirilmesine müdahale ettiği bir tür" roliçi çatışmayı ifade etmektedir (Ko, 2016: 240).

Aile-İş Çatışması: Kişinin ailesiyle ilgili olan sorumlulukları ve ailesinin talepleri, işiule ilgili sorumluluklarının önüne geçtiği zaman oluşan çatışma türün aile-iş çatışması olarak adlandırılmaktadır (Netemeyer, Boles \& McMurrian, 1996: 401). Aile-iş çatışması, "genel taleplerin, ayrılan zamanın ve ailenin oluşturduğu gerginliğin işle ilgili sorumlulukları yerine getirmesini engelleyen" bir rolü-çatışma biçimini ifade etmektedir (Ko, 2016: 240). Örneğin, bir kişi, işine uzun saatler harcayan iyi bir çalışan olmanın bir kimliğini geliştirirse, iyi bir eş olmanın aile kimliğinin onunla zaman geçirmesi gerektiğinde aile-rol kimliği ile çatışma yaşayabilmektedir (Olson, Huffman, Leiva \& Culbertson 2013: 743).

Ancak, yapılan çalışmalarda, iş alanlarının aile alanlarına göre daha az geçirgen olduğu ve bundan dolayı aileden işe çatışmanın işten aileye çatışmadan daha az yaşandığı tespit edilmiştir. Bununla birlikte işin aileyi olumsuz etkilemesi durumunun, ailenin işi olumsuz etkilemesi durumuna nazaran daha yaygın olduğu tespit edilmiștir (Yüksel, 2005: 304).

Choudhary, Ojha \& Singh'in 2015 yılında yayınladıkları makalelerinde çatışma kaynaklarını; yaş, medeni durum, eğitim seviyesi, sahip olunan çocuk sayısı gibi bireysel faktörler; eşin çalışması, uzun çalışma saatleri, iş yükü, rol katılımı, kariyer aşamaları gibi 
örgütsel faktörler; ailenin büyüklügü̈, evin ihtiyaçları, eşin desteğinin olmaması gibi aile ile ilgili faktörler şeklinde ifade etmektedirler.

Cansaran \& Yılmaz (2018) çalışmalarında çalışma ortamlarında kişilerarası ilişkilerin geliştirilmesinin çalışanların iş verimini artıracağı, daha güvenli bir iş ortamının oluşturulacağı ve bu durumun sağlanmasında yöneticilerin önemli görevleri olduğu noktalarına vurgu yapmışlardır. Bu belirtilen noktalardan hareketle; iş ortamında kendisini güvende hisseden bir çalışanın aile ortamında daha az çatışma yaşayacağı ve daha mutlu olacağını da anlamak yanlış olmayacaktır.

\section{YÖNTEM}

\subsection{Araştırmanın Amacı, Örneklemi ve Veri Toplama Aracı}

Çalışmanın amacı çağrı merkezi çalışanlarının demografik özelliklerinin işten aileye ve aileden işe çatışma üzerindeki etkilerini araștırılması ve ortaya çıkarılmasıdır. Bireylerin iş-aile çatışmasını nasıl yönettikleri bu araştırmanın temel problemini oluşturmaktadır. Araştırma çağrı merkezi çalışanları üzerinde gerçekleștirilmiştir. Araştırmada ilgili katılımcılara anket formları dağıtılmış ve anket formlarından 287 tanesi değerlendirilmiştir. Mevcut anket formu toplam 18 sorudan oluşmaktadır. Anket formunun ilk bölümünde kişisel bilgiler ve katılımcıların hakkında bilgi edinme ile ilgili 8 soru; ikinci bölümde iş-aile çatışması ile ilgili 10 soru bulunmaktadır.

Çalışanları yaşadığı iş-aile çatışması düzeyini ölçmek için kullanılan ölçek, Netemeyer Boles \& Mcmurrian (1996) tarafından ortaya konulmuş, Apaydın (2004) tarafından Türkçeye uyarlanmış 10 ifadeden oluşmaktadır. Ölçek iki boyuttan oluşmakta ve $5^{\prime}$ li Likert şeklinde verileri toplamaktadır. Apaydın (2004) tarafından yapılan çalıșmada 5 ifadeden oluşan İșten aileye çatıșma boyutu için $\alpha=0.86$ yine 5 ifadeden oluşan aileden işe çatışma boyutu için güvenilirlik katsayısı $=0.82$ olarak belirlemiştir. Ölçek herhangi bir soru eklenip çıkarılmadan kullanılmıştır.

\subsection{Araştırmanın Modeli ve Hipotezler}

Anket çalışmasıyla çağrı merkezi çalışanlarının demografik değişkenlerinin ile işaile çatışması üzerindeki etkileri belirlenmeye çalışılmıştır. Araştırmamıza ilişskin model Şekil 1'de gösterilmektedir.

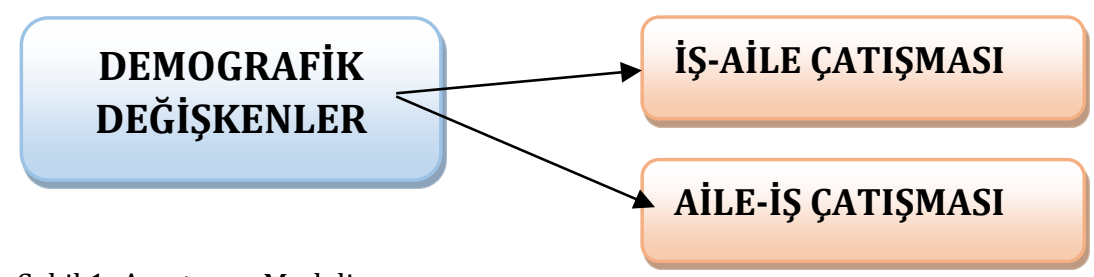

Şekil 1: Araștırma Modeli

Araştırmanın hipotezleri şu şekildedir:

$\mathrm{H}_{1}$ : Cinsiyet değişkenine göre, iş-aile çatışması algısı farklılık göstermektedir.

$\mathrm{H}_{2}$ : Cinsiyet değişkenine göre, aile-iş çatışması algısı farklılık göstermektedir.

$\mathrm{H}_{3}$ : Medeni durum değişkenine göre, iş-aile çatışması algısı farklılık göstermektedir.

$\mathrm{H}_{4}$ : Medeni durum değişkenine göre, aile-iş çatışması algısı farklılık göstermektedir. 
H5: Yaş değişkenine göre, iş-aile çatışması algısı farklılık göstermektedir.

$\mathrm{H}_{6}$ : Yaş değişkenine göre, aile-iş çatışması algısı farklılık göstermektedir.

H7: Çalışma şekli değişkenine göre, iş-aile çatışması algısı farklılık göstermektedir.

$\mathrm{H}_{8}$ : Çalışma şekli değişkenine göre, aile-iş çatışması algısı farklılık göstermektedir.

H9: Alınan eğitim değişkenine göre, iş-aile çatışması algısı farklılık göstermektedir.

$\mathrm{H}_{10}$ : Alınan eğitim değişkenine göre, aile-iş çatışması algısı farklılık göstermektedir.

$\mathrm{H}_{11}$ : Kendini yeterli hissetme değişkenine göre, iş-aile çatışması algısı farklılık göstermektedir.

$\mathrm{H}_{12}$ : Kendini yeterli hissetme değişkenine göre, aile-iş çatışması algısı farklılık göstermektedir.

\section{BULGULAR}

Çağrı merkezi çalışanlarının demografik değişkenlerine ilişkin bulgular şu şekildedir;

Katılımcların \%66,2'si 18-30 yaş aralığında (n=190), \%24'ü 31-43 yaş aralığında ( $n=69), \% 9,8^{\prime} \mathrm{i}$ ise 44 yaş ve üzeri $(\mathrm{n}=28)$ yaş grubundadır; $\% 65,5^{\prime} \mathrm{i}$ kadın $(\mathrm{n}=188), \% 34,5^{\prime} \mathrm{i}$ ise erkektir ( $n=99)$; eğitim durumuna bakıldığında \%38,7'siortaöğretim ( $n=111)$, \%37,6'sı̈nlisans mezunu ( $n=108), \% 23,7$ 'si lisans ve üzeri (n=68); katılımcıların \%62,4'ü bekar $(\mathrm{n}=179), \% 37,6$ 's ise evlidir $(\mathrm{n}=108)$. Katılımclların \%34,5'i 0-1 yll arasında (n=99), \%38,7'si1-3 yıl arasında (n=111), \%17,4'ü3-5 yıl arasında (n=50), \%9,4'ü5-10 yıl arasında (n=27) mevcut kurumda çalışmaktadırlar. Katılımcıların \%31'i devamlı olarak gündüz ya da devamlı olarak gece çalıșmaktadırlar ( $n=89)$, \%69'u ise vardiyalı ( $n=198)$ olarak çalışmaktadırlar. Katılımcıların asıl eğitim aldıkları alan incelendiğinde \%14,6'sı ön lisans çağrı merkezi eğitimi ( $n=89)$ almışken \%85,4'ü diğer alanlarda (n=245) eğitim almıșlardır. Son olarak katılımcıların \%44,3'ü $(n=127)$ kendilerini yaptıkları iş hususunda yeterli görürlerken \%55,7'si (n=160) kendilerini yeterli görmemektedirler.

Yapılan $\mathrm{t}$ testi ve varyans analizlerine göre bazı demografik faktörler ile katılımcıların iş-aile çatışmasına ilişskin anlamlı farklılıklar tespit edilmiştir.

Grup istatistiklerine bakıldı̆̆ında yapılan analizlerde;

Tablo 1. Katılımcıların Cinsiyetleri ile İş-Aile Çatışması ve Aile-İş Çatışmasına İlişkin TTesti Sonuçları

\begin{tabular}{|l|l|l|l|l|l|}
\hline Değișken & Cinsiyet & $\mathbf{N}$ & $\overline{\mathbf{X}}$ & $\mathbf{T}$ & Sig. (p) \\
\hline \multirow{2}{*}{$\begin{array}{l}\text { Iş̧-Aile } \\
\text { Çatışması }\end{array}$} & Erkek & 99 & 13,1717 & $-8,547$ & 0,000 \\
\cline { 2 - 4 } $\begin{array}{l}\text { Aile-İ̧ } \\
\text { Çatışması }\end{array}$ & Kadın & 188 & 18,3032 & & \\
\cline { 2 - 4 } & Kadin & 99 & 15,6263 & $-2,345$ & 0,020 \\
\hline
\end{tabular}

Katılımcıların cinsiyetleri ile iş-aile çatışmasına ilişkin t-testi sonuçları incelendiğinde; ișten aileye çatışma ve aileden ișe yönelik çatışma değişkenlerinde anlamlı bir ilișkinin varlığından söz edilebilmektedir $(\mathrm{p}<0,05)$. Ortalamalara göre kadın çalışanlar erkek çalışanlara göre işten aileye ve aileden işe yönelik çatışmayı daha fazla yaşamaktadırlar. 
Tablo 2. Katılımcıların Medeni Durumları ile İş-Aile Çatışması ve Aile-İş Çatışmasına İlișkin T-Testi Sonuçları

\begin{tabular}{|l|l|l|l|l|l|}
\hline Değişken & $\begin{array}{l}\text { Medeni } \\
\text { Durum }\end{array}$ & $\mathbf{N}$ & $\overline{\mathbf{X}}$ & $\mathbf{T}$ & Sig. (p) \\
\hline $\begin{array}{l}\text { İş-Aile } \\
\text { Çatışması }\end{array}$ & Evli & 108 & 21,4815 & 19,374 & 0,000 \\
\cline { 2 - 4 } $\begin{array}{l}\text { Aile-İş } \\
\text { Çatışması }\end{array}$ & Eekar & 179 & 13,5475 & & \\
\cline { 2 - 4 } & Bekar & 108 & 17,2130 & 2,762 & 0,006 \\
\hline
\end{tabular}

Katılımcıların medeni durumları ile iş-aile çatışmasına ilişkin t-testi sonuçlarına göre; evli katılımcılar ișten aileye ve aileden ișe yönelik çatışmayı bekar çalışanlara klyasla daha fazla yaşamaktadırlar.

Tablo 3. Katılımcıların yaşları ile İş-Aile Çatışması ve Aile-İş Çatışmasına İlişkin Anova Testi Sonuçları

\begin{tabular}{|l|l|l|l|l|}
\hline Değişken & $\begin{array}{l}\text { Yaş } \\
\text { Değişkeni }\end{array}$ & $\begin{array}{l}\text { Ortalama } \\
(\overline{\mathbf{X}})\end{array}$ & F değeri & Sig. (p) \\
\hline İş-Aile Çatışması & $18-30$ & 15,2211 & & \\
& $31-43$ & 18,2464 & 22,464 & 0,000 \\
& 44 ve üzeri & 21,2143 & & \\
\hline Aile-İş Çatışması & $18-30$ & 16,4105 & & \\
& $31-43$ & 16,0290 & 0,688 & 0,503 \\
& 44 ve üzeri & 17,0714 & & \\
\hline
\end{tabular}

Çalıșanların yaşları ile iş-aile çatışması arasındaki anlamlı farklılık işten aileye yönelik çatışma boyutundan kaynaklanmaktadır. Bu doğrultuda; 44 yaş ve üzerindeki katılımcılar işten aileye yönelik çatışmayı daha çok yaşamaktadırlar. Yaş azaldıkça yaşanan çatışma da azalmaktadır. Aileden ișe yönelik çatışma boyutunda anlamlı bir farklılık bulunmamaktadır ( $\mathrm{p}>0,05)$.

Tablo 4. Katılımcıların Çalışma Şekli ile İş-Aile Çatışması ve Aile-İş Çatışmasına İlişskin TTesti Sonuçları

\begin{tabular}{|l|l|l|l|l|l|}
\hline Değişken & $\begin{array}{l}\text { Çalışma } \\
\text { Şekli }\end{array}$ & $\mathbf{N}$ & $\mathbf{( \overline { \mathbf { X } } )}$ & $\mathbf{T}$ & Sig. (p) \\
\hline \multirow{2}{*}{$\begin{array}{l}\text { İş-Aile } \\
\text { Çatışması }\end{array}$} & $\begin{array}{l}\text { Devamlı } \\
\text { gece/gündüz }\end{array}$ & 89 & 16,5393 & 0,13 & 0,990 \\
\cline { 2 - 4 } & Vardiyalı & 198 & 16,5303 & & \\
\hline \multirow{2}{*}{$\begin{array}{l}\text { Aile-İș } \\
\text { Çatışması }\end{array}$} & $\begin{array}{l}\text { Devamlı } \\
\text { gece/gündüz }\end{array}$ & 89 & 15,0674 & $-3,809$ & 0,000 \\
\cline { 2 - 4 } & Vardiyalı & 198 & 16,9747 & & \\
\hline
\end{tabular}

Katılımcıların çalışma şekilleri ile iş-aile çatışmasına ilişkin t-testi sonuçlarına göre; anlamlı farklılık vardiyalı olarak çalışanlardan kaynaklanmaktadır. Vardiyalı çalışanlar aileden işe yönelik çatışmayı devamlı gündüz ya da devamlı gece çalışan katılımcılara göre daha fazla yaşamaktadırlar. İșten aileye yönelik çatışma alt boyutunda ise anlamlı bir farklılık bulunmamaktadır. 
Tablo 5. Katılımcıların Aldıkları Eğitim ile İş-Aile Çatışması ve Aile-İş Çatışmasına İlişkin T-Testi Sonuçları

\begin{tabular}{|c|c|c|c|c|c|}
\hline Değişken & Alınan Eğitim & $\mathbf{N}$ & $(\overline{\mathbf{X}})$ & $\mathbf{T}$ & Sig. (p) \\
\hline \multirow[t]{2}{*}{$\begin{array}{l}\text { İş-Aile } \\
\text { Çatışması }\end{array}$} & $\begin{array}{l}\text { Çağrı Merkezi } \\
\text { Eğitimi }\end{array}$ & 42 & 14,6905 & \multirow[t]{2}{*}{$-2,409$} & \multirow[t]{2}{*}{0,017} \\
\hline & $\begin{array}{l}\text { Diğer Alanlarda } \\
\text { Eğitim }\end{array}$ & 245 & 16,8490 & & \\
\hline \multirow[t]{2}{*}{$\begin{array}{l}\text { Aile-İş̧ } \\
\text { Çatışması }\end{array}$} & $\begin{array}{l}\text { Çağrı Merkezi } \\
\text { Eğitimi }\end{array}$ & 42 & 15,3571 & \multirow[t]{2}{*}{$-1,807$} & \multirow[t]{2}{*}{0,072} \\
\hline & $\begin{array}{l}\text { Diğer Alanlarda } \\
\text { Eğitim }\end{array}$ & 245 & 16,5592 & & \\
\hline
\end{tabular}

Katılımcıların almış oldukları eğitim ile iş-aile çatışmasına ilişkin t-testi sonuçlarına göre; çağrı merkezi eğitiminden farklı bir alanda eğitim almış katılımcılar işten aileye yönelik çatışmayı daha fazla yaşamaktadırlar. Aileden işe yönelik çatışmada ise anlamlı bir farklılık bulunmamaktadır.

Tablo 6. Katılımcıların Kendini Yeterli Hissetme ile İş-Aile Çatışması ve Aile-İș Çatışmasına İlişkin T-Testi Sonuçları

\begin{tabular}{|l|l|l|l|l|l|}
\hline Değișken & $\begin{array}{l}\text { Kendini } \\
\text { Yeterli } \\
\text { Hissetme }\end{array}$ & $\mathbf{N}$ & $\mathbf{( \mathbf { X } )}$ & $\mathbf{T}$ & Sig. (p) \\
\hline \multirow{2}{*}{$\begin{array}{l}\text { İş-Aile } \\
\text { Çatışması }\end{array}$} & $\begin{array}{l}\text { Kendini Yeterli } \\
\text { Hissedenler }\end{array}$ & 127 & 12,8425 & $-12,958$ & 0,000 \\
\cline { 2 - 4 } & $\begin{array}{l}\text { Kendini Yeterli } \\
\text { Hissetmeyenler }\end{array}$ & 160 & 19,4625 & & \\
\hline $\begin{array}{l}\text { Aile-İş } \\
\text { Çatışması }\end{array}$ & $\begin{array}{l}\text { Kendini Yeterli } \\
\text { Hissedenler }\end{array}$ & 127 & 15,4646 & $-3,459$ & 0,001 \\
\cline { 2 - 4 } & $\begin{array}{l}\text { Kendini Yeterli } \\
\text { Hissetmeyenler }\end{array}$ & 160 & 17,1125 & & \\
\hline
\end{tabular}

Katılımcıların kendilerini yeterli hissedip hissetmemeleri ile iş-aile çatışmasına ilişkin t-testi sonuçlarına göre; kendini yeterli hissetmeyen çalışanlar hem ișten aileye hem de aileden işe çatışma yaşamaktadırlar.

Elde edilen bu veriler ışığında $\mathrm{H}_{1}, \mathrm{H}_{2}, \mathrm{H}_{3}, \mathrm{H}_{4}, \mathrm{H}_{5}, \mathrm{H}_{8}, \mathrm{H}_{9}, \mathrm{H}_{11}$ ve $\mathrm{H}_{12}$ kabul edilirken $\mathrm{H}_{6}, \mathrm{H}_{7}$ ve $\mathrm{H}_{10}$ reddedilmektedir.

\section{Sonuç ve Tartışma}

Araştırmamızın sonuçlarına göre; kadın çalışanlar erkek çalışanlara göre işten aileye ve aileden ișe yönelik çatışmayı daha fazla yaşamaktadırlar. Bu durum literatür ile de desteklenmektedir (Aycan \& Eskin, 2005: 461; Sunal, vd., 2016: 147). Birçok çalışmada elde edilen sonuçlar, çağrı merkezi çalışanlarının ağırlıklı olarak kadınlardan oluştuğunu göstermektedir (Werdieger \& Niebuhr, 2000: 31-32). Günümüzde kadınlar iş yaşantısının birçok noktasında etkili konuma gelmektedirler ve yüklenmiş oldukları roller de her geçen gün artmaktadır. Bu durumda kadınlar için iş ve aile çatışması yaşanmasına neden olmaktadır. 
Çalışan kadınlar için çok sayıda rol beklentisi belirgindir. Hem iş hem de aile hayatlarının vazgeçilmez bir parçasıdır ve özellikle her iki alanda da rollerini uzlaştırmak zorundadırlar (Sharma, Dhar \& Tyagi 2016: 268). Kadınlar erkeklerden daha fazla aile sorumluluklarına sahip olma eğilimindedirler (Unruh, Raffenaud \& Fottler 2016: 130) ve erkeklere kıyasla, kadınlar aile beklentilerini karşılamada daha fazla iş-aile çatışması yaşamaktadırlar (Eby, Casper, Lockwood, Bordeaux \& Brinley 2005, s. 126).

Araştırmamızın bir diğer sonucu da evli katılımcıların işten aileye ve aileden işe yönelik çatışmayı bekar çalışanlara kıyasla daha fazla yaşamalarıdır.

Evli çalışanlar, çalışma ve aile sorumluluklarını yerine getirmek için zaman, enerji ve bağlılıklarını sunmak zorundadırlar. Böyle bir durum, çalışanların, eşin ve ebeveyni aynı anda birden fazla görevi üstlenmelerini gerektirmektedir. Örneğin, hafta sonu çalışmak, bir ebeveyinin evde çocuklarıyla ilgilenmesini engelleyebilir. Buna ek olarak, çalışanlar işyeri sorunlarını ve streslerini eve getirdiğinde, aile yaşam kalitesinden olumsuz etkilenebilir. Bu çoklu rollerin talepleri her zaman uyumlu değildir, bu da iş aile çatışmalarının ortaya çıkmasına neden olabilmektedir. İstihdam edilen annelerin rutin hayatlarında çok sayıda rolü nedeniyle rol çatıșmasına maruz kalmaktadırlar (Bakar \& Salleh, 2015, s. 78-79).

Araştırmamızda; 44 yaș ve üzerindeki katılımcılar işten aileye yönelik çatıșmayı daha çok yaşadıkları ortaya çıkmıştır. Yaş azaldıkça yaşanan çatışma da azalmaktadır. Kuzulu, vd., (2013)'ne göre de; 20-30 yaşları arasındaki insanlar 40 yaş ve üstü kişilerle karşılaştırıldığında daha fazla iş ve kişisel hayat çatışmasına sahip olmaktadırlar. Bireylerin yaşı, çatışmanın dolaylı bir nedeni olarak değerlendirilmektedir. Bu duruma göre, bir birey yaşça büyük olursa, çalışma ve aile konusundaki rolleri artabilmektedir.

Araştırmamıza göre; vardiyalı çalışanlar aileden işe yönelik çatışmayı devamlı gündüz ya da devamlı gece çalışan katılımcılara göre daha fazla yaşamaktadırlar ve çağrı merkezi eğitiminden farklı bir alanda eğitim almış katılımcılar işten aileye yönelik çatışmayı daha fazla yaşamaktadırlar. Çağrı merkezi ön lisans eğitimi almış bireyler iş esnasındaki mevcut stres ile nasıl başa çıkmalarını, yaşanan olumsuzluklar karşısında nasıl önlem alabileceklerini çağrı merkezi eğitimi almamış olan bireylere göre daha iyi yönetebilmektedirler ve böylece işten aileye yönelik çatışmayı daha az yaşamaktadırlar.

Kendini yeterli hissetmeyen çalışanlar hem ișten aileye hem de aileden işe çatışma yaşamaktadırlar. Kendini başarısız veya yetersiz hissetme daha çok mesleğe yeni başlamış olanlarda ortaya çıkmaktadır ve deneyim kazanılmasıyla beraber kişilerin kendilerini başarılı ve yeterli hissetmelerinde artışlar meydana gelmektedir. Randall \& Scott, (1988) mesleğine yeni başlayan kişilerde ortaya çıkmakta olan bu tepkiyi; mesleklerine bağlanmalarının henüz tam anlamıyla gerçekleşmemiş olmasıyla açıklamaktadır. Mevcut araştırmada katılımcıların yarısından fazlasının 0-3 yıl arasında çağrı merkezinde çalışıyor olmaları bu durumu açıklar niteliktedir. Çağrı merkezlerinin temel taşını insan sermayesi oluşturmaktadır. İnsan sermayesi kıt ve çok değerlidir, onu değiştirmek ve çoğaltmak zordur, bu yüzden insan sermayesi örgütsel değerleri teşvik edip temel rekabet avantajını güçlendirebilecek bir stratejik varlık olarak düşünülmektedir (Yılmaz \& Kumkale, 2019: 203).

Çağrı merkezlerinde yapılan çalışmalarda çağrı merkezinin çalışmalarının stresli bir çalışma olduğu bulunmuştur. (Taylor \& Bain, 1999; Wallece, Eagleson \& Waldersee, 2000, Deery, Iverson \& Walsh, 2002: 492; Holman, Chissick \& Totterdell, 2002: 682). Çağrı merkezlerinin stresli ortamlar olması iş-aile dengesini olumsuz etkilemekte ve zamanla iş-aile çatışmasına yol açmaktadır.

İş-aile çatışmasının uzun süre devam etmesi, çalışanların hem fiziksel hem de psikolojik sağlıkları üzerinde olumsuz etkiler oluşturabilmektedir. Bu bağlamda ifade edilebilir ki, hem iş-aile çatışması hem de aile-iş çatışması durumlarının etki düzeyleri, yalnızca çatışmanın yaşandığı ortamlarda kalmamaktadır. Bireyin tüm yaşantısını 
etkileyen bu olumsuz faktörler, çatışmaların çözümlenmesinde gereklilik arz etmektedir. Bu bağlamda ifade edilebilir ki, bireyin yaşantısında moral düşüklüğü, isteksizlik, hayal kırıklığı ve tatminsizlik durumları sorunlar oluşturduğundan, çözümlenmesi amaçlı çalışmaların geliştirilmesi, etkinlikleri yansıtmada önemlidir (Erdem \& Erkan 2015: 353). İş-aile çatışmasının en aza indirilebilmesi için; kişilerde öz yeterliliğin geliştirilmesi, bireylere sosyal desteğin (aile, arkadaşlar) sağlanması, gerekli görüldüğünde psikolojik destek alınması, işletmelerde esnek çalışma saatlerinin oluşturulması gerekli olabilecektir.

Araştırmada çeşitli sonuçlara ulaşılmasına rağmen bazı kısıtlar da bulunmaktadır. Çalışma, Erzincan'daki bir çağrı merkezinde gerçekleştirilmiştir ve seçilen örneklem sayısı kuramsal açıdan yeterli görülse de genelleme yapılacak büyüklükte değildir. $\mathrm{Bu}$ nedenle daha büyük bir örneklem ve başka çalışmalar ile de desteklenebilir. Ayrıca iş aile çatışması farklı değișkenler ile de ilişkilendirilerek yeni sonuçlar ortaya çıkarılabilecektir.

\section{KAYNAKÇA}

AKTAŞ, H. \& GÜRKAN, G. Ç. (2015). İş-aile ve aile-iş çatışması ile bireysel performans etkileşiminde mesleki bağlılığın aracı rolü: Hemşireler üzerinde bir araştırma. Doğuş Üniversitesi Dergisi, Cilt 16 (2), 139-154.

APAYDIN, M. D. (2004). Çift kariyerli ailelerde iş-aile ve aile-iş çatışmalarının kendini kurgulama düzeyleri ile ilișkisi. Yayımlanmamıș Yüksek Lisans Tezi, Hacettepe Üniversitesi, Sosyal Bilimler Enstitüsü, Ankara.

AY, K. \& KUMKALE, İ. (2020). The role of manager values the impact of ethical codes on competetive advantage. Academy of Strategic Management Journal, Cilt 19 (1), $1-24$.

AYCAN, Z. \& ESKIN, M. (2005). Childcare, spousal, and organizational support in predicting work-family conflict for females and males in dual-earner families with preschool children. Sex Roles, 53, 453-471.

BAKAR, Z. A. \& SALLEH, R. (2015). Role demands, work-family conflict and motivation: A proposed framework. Global Business and Management Research, Cilt 7 (2), 78-87.

BAȘBUĞ, G., BALLI, E. \& OKTUĞ, Z. (2010). Duygusal emeğin iş memnuniyetine etkisi: çağrı merkezi çalışanlarına yönelik bir çalışma. Sosyal Siyaset Konferansları Dergisi, (58), 253-274.

BATT, R. \& MOYNIHAN, L. (2002). The viability of alternative call centre production models. Human Resource Management Journal, Cilt 12 (4), 14-34.

CANSARAN, D. \& YILMAZ, F. (2018). Etik liderlik davranışının kişilerarası davranışının kişilerarası ilişki boyutları üzerine etkileri: Göynücek ilçesi kamu kurumlarında bir uygulama. Verimlilik Dergisi, (2), 163-181.

CARLSON, D. S. (1999). Personality and role variables as predictors of three forms of work-family conflict. Journal of Vocational Behavior, Cilt 55 (2), 236-253.

CHOUDHARY, N., OJHA, S. \& SINGH, K. N. (2015). Linkingwork-familyandfamilyworkconflicttodemographicdeterminants: a study on officers of a defencecpse in bangalore. Journal of Institute of Public Enterprise, Cilt 38 (1-2), 129-149.

ÇARIKÇI, İ. H. \& ÇELIKKKOL, Ö. (2009). İş-aile çatışmasının örgütsel bağlılık ve ișten ayrılma niyetine etkisi. Süleyman Demirel Üniversitesi Sosyal Bilimler Enstitüsü Dergisi, Cilt 1 (9), 153-170.

DEERY, S., IVERSON, R. \& WALSH, J. (2002). Work relationships in telephone call centres: Understanding emotional exhaustion and employee withdrawal. Journal of Management studies, Cilt 39 (4), 471-496. 
DIXON, A. M. \& BRUENING, E. J. (2005). Perspectives on work famliy conflict sport: An integrated approach. Sport Management Review, Cilt 8 (3), 227-253.

EBY, L. T., CASPER, W. J., LOCKWOOD, A., BORDEAUX, C. \& BRINLEY, A. (2005). Work and family research in IO/OB: Content analysis and review of the literature (1980-2002). Journal of Vocational Behavior, Cilt 66 (1), 124-197,

EFEOĞLU, E. \& ÖZGEN, H. (2007). İş aile yaşam çatışmasının iş stresi iş doyumu ve örgütsel bağlılık üzerindeki etkileri: ilaç sektöründe bir araștırma. Çukurova Üniversitesi Sosyal Bilimler Enstitüsü Dergisi, Cilt 16 (2), 237-254.

ERDEM, H. \& ERKAN, G. K. (2015). Kamu çalışanlarının yaşadıkları iş-aile ve aileiş çatışmasının iş tatminsizliğine olan etkisinde örgütsel sinizmin aracılık rolü. The Journal of Academic Social Science Studies, (37), 351-369.

GIRAY, D. M. \& ERGIN, C. (2006). Çift-kariyerli ailelerde bireylerin yaşadıkları işaile ve aile-iş çatışmalarının kendini kurgulama davranışı ve yaşam olayları ile ilişkisi. Türk Psikologlar Dergisi, Cilt 21 (57), 83-101.

GREENHAUS J. H. \& BEUTELL, N. J. (1985). Sources of conflict between work and family roles. Academy of Management Review Cilt 10(1): 76-88.

HOLMAN, D., CHISSICK, C. \& TOTTERDELL, P. (2002). The effects of performance monitoring on emotional labor and well-being in call centers. Motivation and Emotion, Cilt 26 (1), 57-81.

KALLIATH, P. \& KALLIATH, T. (2013). Work-family conflict and iş tatmini simpact on jobsatisfaction of socialworkers. British Journal of Social Work, Cilt 45(1), 241-259.

KESER, A. (2006). Çağrı merkezi çalışanlarında iş yükü düzeyi ile iş doyumu ilișkisinin araştırılması. Kocaeli Üniversitesi Sosyal Bilimler Dergisi, Cilt 11 (1), 100-119.

KO, C. H. (2016). Exploring the relationship of conflict between family and work among hotel employees. International Journal of Organizational Innovation (Online), Cilt8 (3), 239-247.

KUZULU, E., KURTULDU, S. \& ÖZKAN, G. V. (2013). İş yașam dengesi ile iș doyumu ilișkisi üzerine bir araștırma. Sakarya Íktisat Dergisi, Cilt 2 (5), 88-127.

LAMBERT, E. G., QURESHI, H., FRANK, J., KEENA, L. D. \& HOGAN, N. L. (2017). Therelationship of work-family conflict with job stres among Indian police officers: a researchnote. Police Practice and Research, Cilt18 (1), 37-48.

LEWIG, K. A. \& DOLLARD, M. F. (2003). Emotional dissonance, emotional exhaustion and job satisfaction in call center. European Journal of Work and Organizational Psychology, Cilt 12 (4), 366-392.

LU, C. C., CHENG, T. M. \& HUANG, S. J. (2016). The impact of the causality between work-family conflict, well-being, and leisurecoping strategies on tour professionals. Journal of Travel \&Tourism Marketing, Cilt 33(7), 1028-1050.

MOZAFARI, M., AZAMI, G., DEHKORDI, M. L. \& AAZAMI, S. (2016). Validation of multi dimensional Persian version of the work-family conflict question naire among nurses. The International Journal of Occupational and Environmental Medicine, Cilt7 (3), 748-164.

NETEMEYER, R. G., BOLES, J. S. \& MCMURRIAN, R. (1996). Development and validation of work-family conflict and family-work conflict scales. Journal of Applied Psychology, Cilt 81 (4), 400-409.

OLSON, K. J., HUFFMAN, A. H., LEIVA, P. I. \& CULBERTSON, S. S. (2013).

Acculturation and individualism as predictors of work-family conflict in a diverse work force. Human Resource Management, Cilt 52 (5), 741-769.

ÖZ, Ü. E. (2007). Duygusal emek davranışlarının çalışanların iş sonuçlarına etkisi. İstanbul: Beta Yayınları. 
ÖZDEVECIOĞLU, M. \& AKTAŞ, A. (2007). Kariyer bağlılı̆̆ı, mesleki bağlılık ve örgütsel bağlılığın yaşam tatmini üzerindeki etkisi: iş-aile çatışmasının rolü. Erciyes Üniversitesi İktisadi ve İdari Bilimler Fakültesi Dergisi, 28, 1-20.

PARLAK, Z. \& ÇETIN, B. I. (2007). Bilgi toplumu ve bilgi işçisi bağlamında çağrı merkezleri: emek süreci, iş ve istihdam. Sosyal Siyaset Konferansları, 52, 107-134.

PRAHABKAR, P. M.J, S. \& COPPETT, J. (1997). The power of technology in business selling: call centers. Journal of Business and Industrial Marketing, 12, 222- 235.

RANDALL, M. \& SCOTT, W. A. (1988). Burnout, job satisfaction, and job performance. Australian Psychologist, Cilt 23 (3), 335-347.

SELEK ÖZ, C. \& MAN, F. (2007). Çalışan bedenin düşen son kalesi: duygular-çağrı merkezi çalışanlarının duygusal emek süreçleri. 15. Yönetim ve Organizasyon Kongresi. 25-27 Mayıs, Sakarya Üniversitesi.

SHARMA, J., DHAR, R. L. \& TYAGI, A. (2016). Stress as a mediator between workfamily conflict and psychological health among the nursing staff: Moderating role of emotional intelligence. Applied Nursing Research, 30, 268-275.

SUNAL, A. B., OK, A. B. \& KESKIN, S. (2016). İş-aile çatışması boyutları ile mükemmeliyetçilik arasındaki ilişkide evlilik doyumunun düzenleyici rolü. Ankara Üniversitesi Dil ve Tarih-Coğrafya Fakültesi Dergisi, Cilt 56 (1), 144-162.

TAYLOR, P. \& BAIN, P. (1999). An assembly line in the head: work and employee relations in the call centre. Industrial Relations Journal, Cilt 30 (2), 101-117

UNRUH, L. Y., RAFFENAUD, A. \& FOTTLER, M. (2016). Work-family conflict among newly licensed registered nurses: a structural equation model of antecedents and outcomes. Journal of Healthcare Management, Cilt 61 (2), 129-145.

WALLECE C., EAGLESON G. \& WALDERSEE R. (2000), The sacrificial HR strategy in call centers, International Journal of Service Industry Management, Cilt 11 (2), 174-184

WAYNE, J. H., MUSISCA, N. \& FLEESON, W. (2004). Considering the role of personality in the work-family experience: relationships of the big five to work-family conflict and facilitation. Journal of Vocational Behavior, Cilt 64 (1), 108-230.

WERDIGIER, W. \& NIEBUHR, A. (2000). Euro-telework: trends and Scenarios. Telework and Call Centers. Disponível em: http://www. telework-mirti. org/dbdocs/werdigie. pdf. Acesso em, 21.

WIRTZ, J. (2000). Growth of the service sector in Asia. Singapore Management Review, Cilt 22 (2), 37-54.

YILMAZ, F. (2019). Kadının iş yaşamı ve etik. (Ed. İlknur Kumkale). Ankara: Nobel Akademik Yayıncılık.

YILMAZ, F. \& KUMKALE, İ. (2019). İşletmelerin faaliyet alanı sınırlarına göre entelektüel sermaye ve firma performansının değerlendirilmesi. Trakya Üniversitesi Sosyal Bilimler Dergisi, 21, 199-214.

YÜKSEL, İ. (2005). İş aile çatışmasının kariyer tatmini ve iş tatmini davranışları ile ilişkisi. Íktisadi ve İdari Bilimler Dergisi, Cilt 19 (2), 301- 314.

ZAPF, D., ISİC, A., BECHTOLDT, M., \& BLAU, P. (2003). What is typical for call centre jobs? job characteristics, and service interactions in different call centres. European Journal of Work and Organizational Psychology, Cilt 12 (4), 311-340.

\section{Summary}

Business family conflict is expressed as the type of conflict experienced by people in mutually in consistent roles in the situation of work and family area. In the literature, different types of work-family conflicts are put forward according to the time that the 
employees allocate for their jobs and their families, the psychological distress of the employees and their social relations within thesociety. When the literature on the subject is examined, it is seen that thereare three types of work-family conflict. The seare: Time based conflict, conflict based conflict and behavior based conflict. It is not unilateral as a workfamily conflict and it is realized between work and family areas. Accordingly, aspects of work-family conflict are: Work-family conflict and family-work conflict. The work-family conflict is bidirectional, which means that business issues can lead to conflict at home or that home problems can cause conflict in the work place. The work-family conflict was deal with in the work of the family from work to family, which made it difficult to fulfill the family responsibilities of work-related demands, conflict, and family-related demands.

The aim of this study is to investigate the effects of the demographic characteristics of the call center employees on the conflict from work to family and from family to work. According to the results of our research; According to male employees, female workers live more from work to family and from family to conflict. This situation is supported by the literature. Nowadays, women have an effective position at many points in their business life and their roles have been increasing day by day. In this case, it causes women and family conflict. Another result of our study is that married participants live more from work-tofamily and family-based conflicts than single workers. Married employees mus tprovide time, energy and commitment to fulfill their work and family responsibilities. Such a situation requires employees, spouse and parentto take on more than one task at the same time. Our research; Participants over theage of 44 years were more likely to experience family conflict. As the agedecreases, the conflict is decreasing. According to Kuzulu, et al. personal life conflicts than peopleaged 40 and over. The age of individuals is considered as an indirect cause of conflict. According to this situation, if an individual is older, their role in working and family can be increased. According to our research; shift workers are more likely to live in family conflicts than those working in the day time or continuousnight, and participants who are trained in a different area of call center experience are more likely to experience work-related conflict. Call center pre-graduate individuals can beter manage how they deal witht he current stres during work and how they can take Measures against the negativities in the workplace. Employees who do not feel self-sufficient experience both family and family conflicts. Feeling unsuccessfulorinsufficient arises in those who have juststarted a profession, and with the acquisition of experience, there is an increase in people's ability to feel successful and sufficient.

In order to minimize the work-family conflict; It may be necessary to develop selfefficacy in individuals, to provide social support (family, friends) to individuals, to obtain psychological support when necessary, to establish flexible working hours in enterprises. 